\title{
STUDY OF SOME ARCHAEOMETRIC CHARACTERISTICS USED IN PANEL PAINTING ICONS AUTHENTICATION
}

\author{
Raluca Anamaria Cristache*, Ana Maria Budu, Petronela Spiridon, \\ Viorica Vasilache, Ion Sandu \\ Interdisciplinary Research and Education Platform ARHEOINVEST, Laboratory of Scientific Investigation and Conservation of \\ Cultural Heritage, Alexandru Ioan Cuza University of Iasi, 11, Carol I blvd., Iasi 700506, Romania \\ *e-mail: raluca_cristache@yahoo.com; phone: +40 0766407927
}

\begin{abstract}
The authentication of cultural heritage assets is a complex process of scientific investigation which regards obtaining information about: author (painter), the period when it was made, the owners and other data related to the main contexts of their evolution in time (routes travelled). In fact, the identification of specific archaeometric features is aimed, in determining the materials composition and the patina, then the study of artistic techniques and technology used in the making process of a work of art. Latest serves to define the patrimonial elements and the role of the artifact in time. The expertise of old panel painting icons requires an interdisciplinary approach, correlating the artistic style with technique and materials used. In this regard, the specific techniques of microscopy and spectroscopy are very useful tools for determining the composition of structural elements and their deterioration / degradation state. This work presents a comparative study of the paper used in the preparation layer of three icons painted in Russian style. As an analysis techniques were used the micro and macro photography assisted by Optical Microscopy (OM), SEMEDX and micro-FTIR. Based on the experimental data obtained, it was found that the icons belong to the first half of the $19^{\text {th }}$ century.
\end{abstract}

Keywords: icon, historic paper, SEM-EDX, micro-FTIR.

\section{Introduction}

Icons are works of art painted, in general, on wood (lime wood, fir, oak). In their creation process painters used different materials, organic and inorganic. Usually, canvas was glued on the panel made of one or more planks. After that, a ground layer, obtained from animal glue and calcium sulfate or calcium carbonate, was applied. Sometimes, instead of canvas, paper was used, glued on the entire surface or only on certain area of planks joint or on the margins. After finishing the ground, the drawing was made and painting was made with tempera or oil. Many times the background of the icon was made with golden or silver leaf which was covered with a colored varnish (shellac), to give the impression of gold [1].

The characteristics of the materials used in creating these icons may help in their dating and authentication. For example, the structure of the paper glued on the wooden support can offer information. The paper was created first by Chinese people in the $3^{\text {rd }}$ century BC, from ground and macerated rags and reeds until they become a paste. Europeans began to made paper from $11^{\text {th }}$ century (Spain and Italy) [2].

Until 1800 the paper continued to be made of hemp and flax rags, their selection depending on material texture. The paste obtained by mechanical processing was diluted with water and then left for drying on a wire net. Because water could contain iron oxides which gave paper a red shade, calcium carbonate was added in the paste. For a higher resistance of paper it was used gelatin and alum $\left(\mathrm{KAl}\left(\mathrm{SO}_{4}\right)_{2} \cdot 12 \mathrm{H}_{2} \mathrm{O}\right)$, that had a conservation role [3].

From the beginning of $19^{\text {th }}$ century there are used colored rags which usually are bleached. The blue paper, made of rags from the navy uniforms, was the cheapest [4].

At the same time, the gelatin is replaced by rosin treated with soda or combined with paraffin. Aluminum sulfate was added in the mixture to increase adhesion. Since 1826 rosin is generally used. After 1840, mechanically or chemically processed wood is used in paper production.

Chemical processing of wood developed around 1850. This type of paper didn't contain lignin, which was dissolved by chemical substances. $50 \%$ of wood mass was lost this way. In 1874, and in 1878 chemical procedures that involved sulfites, respectively sulfates were introduced. In 1867 paper was made by mechanical processing. It contained the principal components of wood: lignin, cellulose and hemicelluloses but it was low quality, used mainly for newspapers [5]. The wood pulp paper also contains additives like coloring agents, coagulants and protective layers [6]. One of the differences between rags paper and wood pulp paper is that the rags fibers are made from linear long cellulose fibers [7].

The aim of this paper is the authentication and dating of three panel painting icons by analyzing the natural materials used in the making process: paper made from rags with cellulosic fibers and binding materials.

\section{Materials and techniques}

For analysis we used three samples of paper taken from three orthodox icons painted in Russian style, tempera on wood: Saint Nicholas - SN (Figure 1), The Holy Virgin of Kazan, copy - HVK (Figure 2), and Saint Anastasia - SA

Presented at the International Conference dedicated to the $55^{\text {th }}$ anniversary from the foundation of the Institute of Chemistry of the Academy of Sciences of Moldova 
(Figure 3). The paper was glued by the original artist on the entire panel surface or on the margins, after that ground was applied over it. The samples were taken from the lacunae and analyzed by different techniques in order to obtain information regarding the methods and materials used.

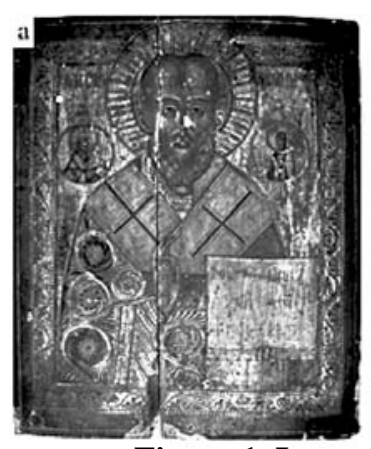

Figure 1. Icon of St. Nicholas: a- front view; b- lacunae detail.
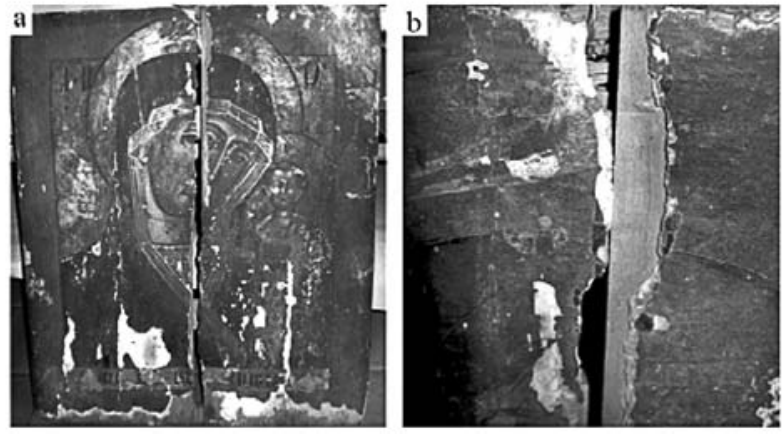

Figure 2. Icon Holy Virgin of Kazan: a- front view; b- lacunae detail.
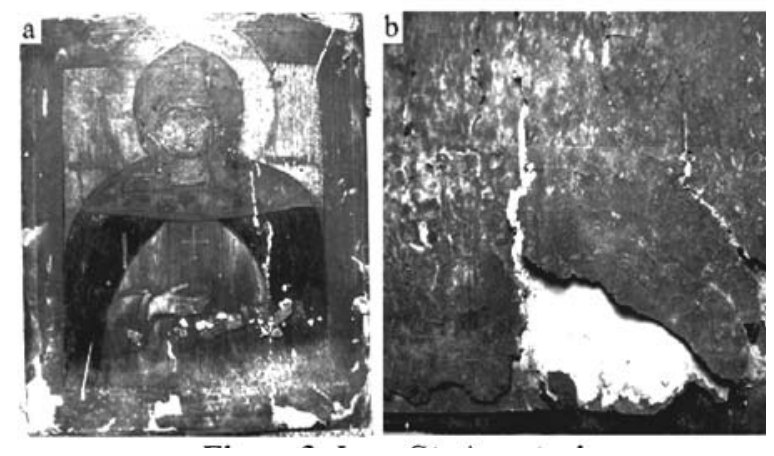

Figure 3. Icon St. Anastasia:

a- front view; b- lacunae detail.

First all samples were analyzed by light microscopy by reflection CARL ZEISS AXIO IMAGER A1m, with attached camera AXIOCAM, images being increased between 50x and 500x. To identify the chemical elements, we have used an electron microscope (SEM-EDX), model VEGA II LSH, made by TESCAN Czech Republic, coupled with an X-ray spectrometer QUANTAX QX2, produced by BRULER/PROENTEC Germany. FT-IR spectra were recorded with a FT-IR spectrometer coupled with a microscope HYPERION 1000, both from Brüker Optic Equipment, Germany.

\section{Results and discussion}

The samples were first analyzed with the help of optical microscopy (OM) by reflection, ranged between 50x and 500x, and photographed. The most edifying images (at magnifications of 50x and 200x) were chosen, so we could have a clear image of the papers structures.

The paper used for SN icon has a dark blue-grey color (Figure 4). As we can see in the images obtained by OM, the paper paste is a mixture of white and long, dark blue fibers. The paper sample from HVK is white-yellow, with a fine texture (Figure 5). The microscopic images show that the fiber net is much tighter, the paste being more processed.
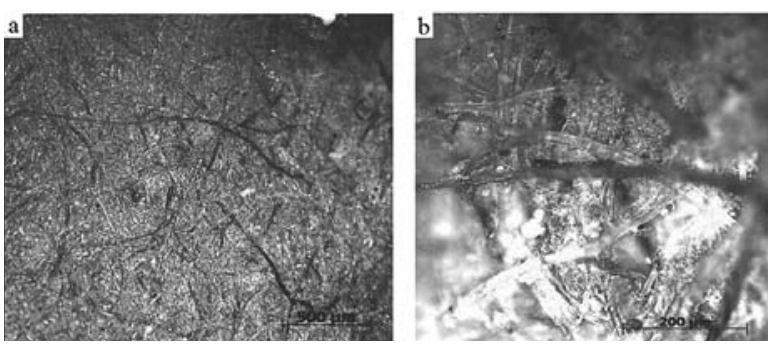

Figure 4. Images of paper sample from $\mathrm{SN}$ icon, obtained by OM: a- 50x; b-200x.
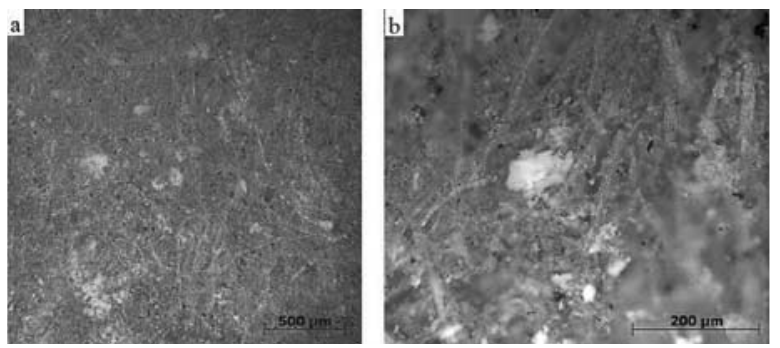

Figure 5. Images of paper sample from HVK icon, obtained by OM: a-50x; b-200x. 

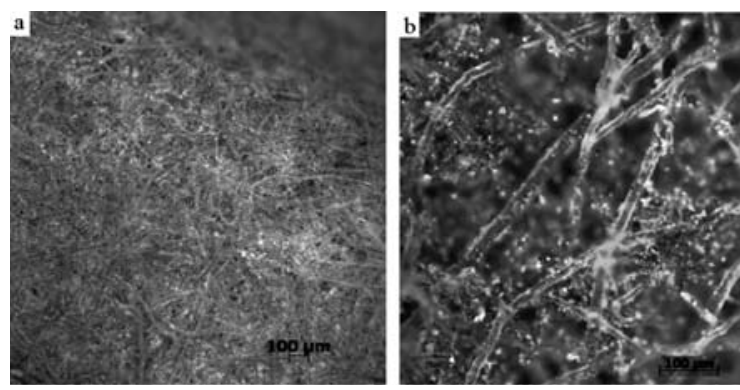

Figure 6. Photos of paper samples from SA icon, by OM: a-50x, b-200x.

For the identification of elemental composition of paper samples electronic microscopy was used (SEM-EDX) and also Micro-FTIR. Regarding the elemental composition of papers, SEM-EDX analysis identified a series of chemical elements which correspond to the substances mentioned in the manufacturing of historic paper.

Table 1

Elemental composition of the paper samples (wt.\%).

\begin{tabular}{cccccccccccccc}
\hline Sample & $C$ & $\mathrm{Ca}$ & $\mathrm{S}$ & $\mathrm{Si}$ & $\mathrm{Fe}$ & $\mathrm{K}$ & $\mathrm{Al}$ & $\mathrm{Mg}$ & $\mathrm{Na}$ & $\mathrm{P}$ & $\mathrm{Cl}$ & $\mathrm{Pb}$ & $\mathrm{O}$ \\
\hline $\mathrm{SN}$ & 16.97 & 1.86 & 1.64 & 0.76 & - & 0.62 & 0.23 & 0.28 & 0.85 & - & 0.79 & - & 75.96 \\
\hline $\mathrm{HVK}$ & 15.44 & 3.19 & 2.17 & 1.36 & 0.52 & 0.47 & 0.62 & 0.39 & 0.57 & 0.33 & 0.36 & 3.64 & 70.88 \\
\hline SA & 13.12 & 3.47 & 0.49 & 1.83 & 0.86 & 0.75 & 0.84 & 0.32 & 0.71 & 0.14 & 0.44 & - & 76.98 \\
\hline
\end{tabular}

SEM-EDX analysis of paper samples from SN, HVK and SA icons revealed that $\mathrm{Ca}, \mathrm{Na}, \mathrm{Si}, \mathrm{K}, \mathrm{Al}$ and $\mathrm{Mg}$ are in higher quantities and are representative for all the samples. Fe and P appear only in two samples (HVK and SA) (Figure 7). All samples contain $\mathrm{Si}, \mathrm{Cl}$, and $\mathrm{S}$. The results are given as percents, but they are only relative percents which include the organic part $(\mathrm{C}, \mathrm{H}$, and $\mathrm{O})$.

Calcium is present in paper composition. Calcium carbonate, which is a universal filler is present in all three samples analyzed and was used not only for the degree of white, but for the brightness that gives to the paper. Its major advantage is that it does not decrease the mechanical strength of the paper, as do other fillers [9]. The presence of K, Al, $\mathrm{S}$ in all the samples, in different quantities, suggests the use of alum in paper processing. It also shows the paper belongs to the $19^{\text {th }}$ century. $\mathrm{Fe}, \mathrm{Ba}, \mathrm{Mg}, \mathrm{Na}$ and $\mathrm{K}$ may appear in the samples as impurities from alum or water [10].
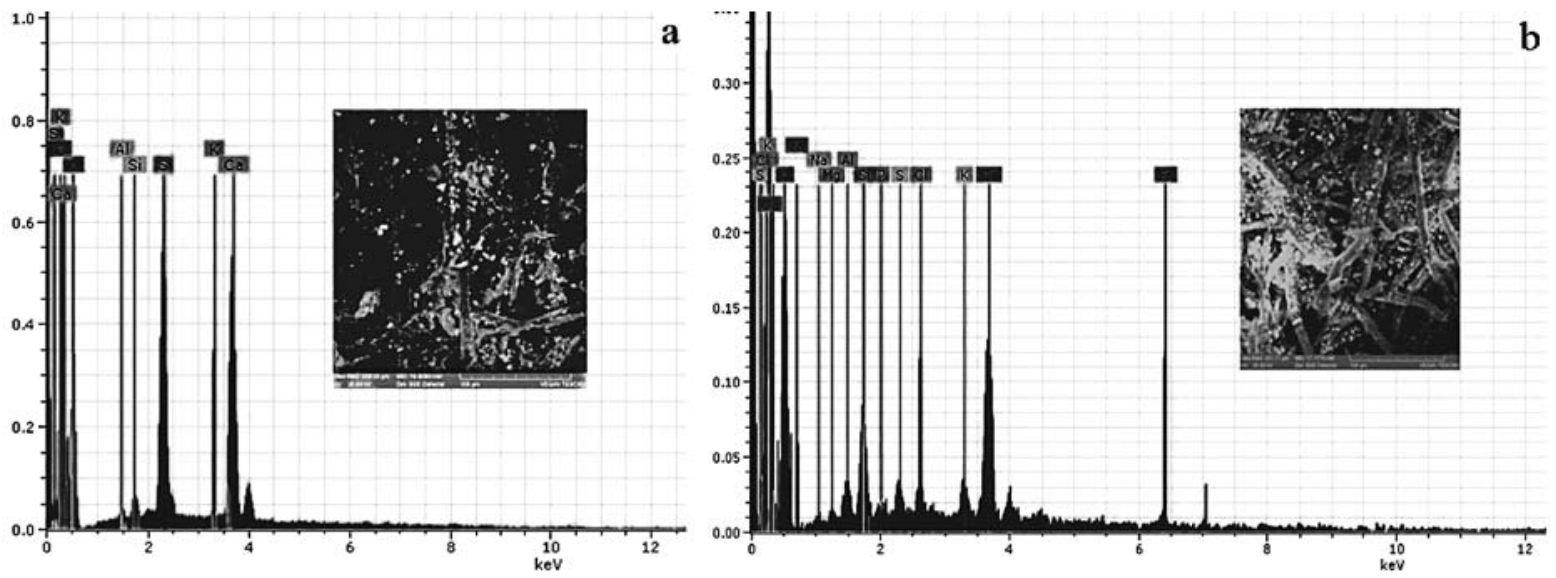

Figure 7. Microphotos and EDX spectra of samples: a- HVK, b- SA.

The presence of $\mathrm{Mg}$ in small quantities also may suggest that talcum $\left(3 \mathrm{MgO} \cdot 4 \mathrm{SiO}_{2} \cdot \mathrm{H}_{2} \mathrm{O}\right)$ was used as filler. Because talcum is soft and greasy it made the paper opaque and soft.

The sulfur is one of the chemical elements that appear in all samples, HVK paper having the biggest quantity $(2.17 \%)$, while SA paper has the smallest sulfur percentage (0.49\%). The high quantity of S from HVK and SN samples is given by the presence of ground, which contains $\mathrm{CaSO}_{4}$. The smaller mass of $\mathrm{S}$ in the third sample might be explained by a smaller concentration of ground or alum. 
Also, traces of $\mathrm{Cl}$ were found in the samples, due to the fact that sodium hypochlorite was used as a bleaching agent [10]. The percentage of $\mathrm{Cl}$ is higher in the SN sample $(0.79 \%)$, where are more blue fibers.

The books which contain recipes for paper manufacturing indicate the use of phosphates as fillers (e.g. calcium phosphate), which explains the presence of $\mathrm{P}$ in the samples [11]. The phosphorus quantity in HVK sample is $0.33 \%$, and only $0.14 \%$ in SA sample.

$\mathrm{Pb}$ is the only element which appears only in the HVK sample and in high concentration (3.64\%). This fact helps us to date the paper sample from the first half of $19^{\text {th }}$ century, because since 1827 the paper was covered with a few layers of lead white $\left(2 \mathrm{PbCO}_{3} \cdot \mathrm{Pb}(\mathrm{OH})_{2}\right)$, enamel paper was made with lead white, isinglass, gum, and animal size [12]. After that the paper sheets were burnished by plating or by rolling with a steel plate [12-14]. The lead white was forbidden since the beginning of $20^{\text {th }}$ century, due to its toxicity.

The results obtained by SEM-EDX were compared with FTIR spectra of paper samples (Figure 8).
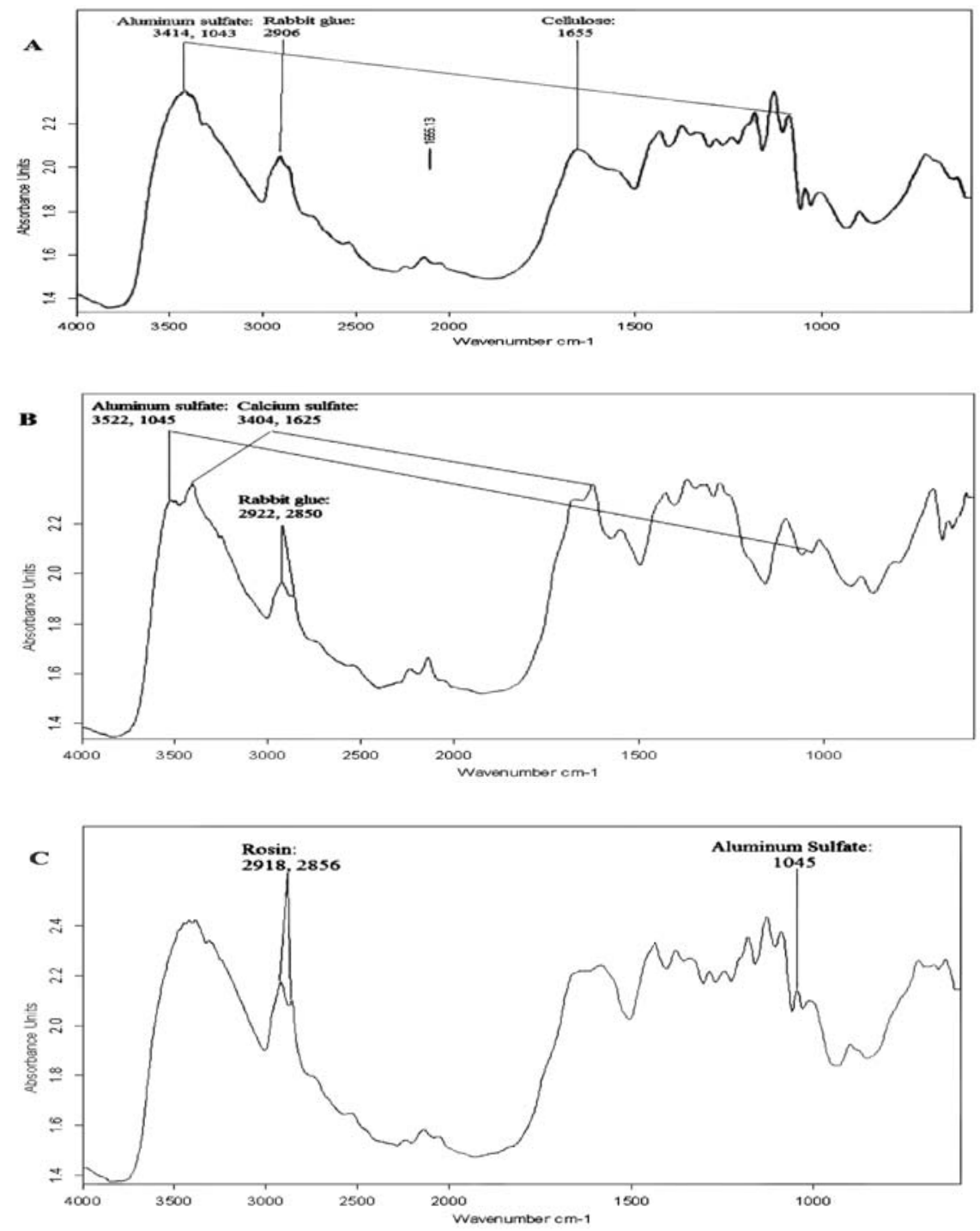

Figure 8. FTIR spectra: A - SN, B - HVK, C - SA.

The fillers were identified as calcium sulfate dihydrate $\left(\mathrm{CaSO}_{4} \cdot 2 \mathrm{H}_{2} \mathrm{O}\right)$, aluminum sulfate $\left(\mathrm{Al}_{2}\left(\mathrm{SO}_{4}\right)_{3} \cdot 18 \mathrm{H}_{2} \mathrm{O}\right)$, talcum $\left(3 \mathrm{MgO} \cdot 4 \mathrm{SiO}_{2} \cdot \mathrm{H}_{2} \mathrm{O}\right)$, rosin and rabbit glue. These substances present specific absorption bands: $\mathrm{CaSO}_{4} \cdot 2 \mathrm{H}_{2} \mathrm{O}-$ $3404 \mathrm{~cm}^{-1}, 1685 \mathrm{~cm}^{-1}, 1625 \mathrm{~cm}^{-1}$, and $666 \mathrm{~cm}^{-1}$, talcum- $1045 \mathrm{~cm}^{-1}$ and $669 \mathrm{~cm}^{-1}$, and $\mathrm{Al}_{2}\left(\mathrm{SO}_{4}\right)_{3}-3522 \mathrm{~cm}^{-1}$ and $1045 \mathrm{~cm}^{-1}$ (Table 2) [15].

Rosin has absorption bands at $2922 \mathrm{~cm}^{-1}, 1697 \mathrm{~cm}^{-1}, 1365 \mathrm{~cm}^{-1}, 1275 \mathrm{~cm}^{-1}, 1106 \mathrm{~cm}^{-1}, 809 \mathrm{~cm}^{-1}, 707 \mathrm{~cm}^{-1}$ [16]. The peaks from $1550 \mathrm{~cm}^{-1}$ and $1656 \mathrm{~cm}^{-1}$ are representative for proteins, but they are superimposed on the representative band for cellulose $\left(1635 \mathrm{~cm}^{-1}\right)$. Their presence might be observed at $1625 \mathrm{~cm}^{-1}$ and $1551 \mathrm{~cm}^{-1}$ [17].

The HVK paper sample, which has in composition white lead mixed with rabbit glue has representative peaks at $2922 \mathrm{~cm}^{-1}, 2850 \mathrm{~cm}^{-1}$ and $1739 \mathrm{~cm}^{-1}$ (Figure 8, Table 2) [18]. 
Identified peaks by micro-FTIR for the three paper samples, between $4000 \mathrm{~cm}^{-1}$ and $600 \mathrm{~cm}^{-1}$.

\begin{tabular}{lllll}
\hline Sample & Peaks, $\mathrm{cm}^{-1}$ \\
\hline SN & 341433042906254121241655143413751283124111791127108810431005898 & \\
\hline HVK & 35223404292222342136162515511429131713201283110610451012899 & 707 & 666619 \\
\hline SA & 33873309291828552541223321352060158214311374133612821241117711251086 \\
& 10431009898712671638 & & &
\end{tabular}

\section{Conclusions}

The microscopic structure of paper (textile fibers) suggests that the icons belong to the first half of the $19^{\text {th }}$ century. The presence of blue fibers in the SN paper sample shows us the icon belongs to the beginning of $19^{\text {th }}$ century. Also the chemical composition allows us to approximate the period when the paintings were realized. For example, the lead content of HVK paper corroborated with the fibers aspect indicates us the icon was painted in the first half of the $19^{\text {th }}$ century, when the paper was coated with lead. The fillers in all the icons were identified as calcium sulfate dihydrate, aluminum sulfate (alum), talcum, rosin and rabbit glue. These materials can help in the authentication and dating of art works, especially because they are an inner part of the icons, an intermediate layer between the support and the ground.

\section{References}

1. Espinola, V.B.-B., Russian Icons: Spiritual and Material Aspects. Journal of the American Institute for Conservation, 1991-1992, 31 (1), pp. 17-22.

2. Radu, M.; Repanovici A., A history of printing and prints. Transilvania: Brasov, 2004, (in Romanian) http://www. unitbv.ro/faculties/biblio/istoria/my\%20web/pdf/Cap\%204.pdf

3. Barrett, T., European Papermaking Techniques 1300-1800. http://paper.lib.uiowa.edu/european.php

4. Paper, http://comminfo.rutgers.edu/ lesk/spring06/lis556/P-paper.pdf

5. Graphic Documents, http://webworld.unesco.org/safeguarding/en/pdf/txt_grap.pdf

6. Laguardia, L.; Vassallo, E.; Cappitelli, F.; Mesto E.; Cremona, A.; Sorlini, C.; Bonizzoniv, G. Elemental identification of document paper by X-ray fluorescence spectrometry. Applied Surface Science, 2005, 252, pp. 164-170.

7. Manso, M.; Costa, M.; Carvalho, M.L. Comparison of elemental content on modern and ancient papers by EDXRF. Applied Physics A, 2008, 90, pp. 43-48.

8. Brückle, I., The Role of Alum in Historical Papermaking. Abbey Newsletter, 1993, 17(4), pp. 53-57.

9. Espadaler, I.; Sistach, M.C.; Cortina, M.; Eljarrat, E.; Alcaraz, R.; Cabañas, J.; Rivera, J.; Organic and inorganic components of manuscript inks. Anales de Quimica, 1995, 91, pp. 359-364.

10. Roberts, J.C. The Chemistry of paper. RSC PAPERBACKS, Cambridge, 1996, $190 \mathrm{p}$.

11. Wagner, B.; Bulska, E.; Hulanicki, A.; Heck, M.; Ortner, H. M. Topochemical investigation of ancient manuscripts. Fresenius' Journal of Analytical Chemistry, 2001, 369, pp. 674-679.

12. van der Reyden, D.; Mosier, E.; Baker, M.; Pigment-coated papers I \& II: history and technology, Triennial meeting (10th), Washington, DC, 1993, 498 p.

13. Hunter, D. Papermaking: The History and Technique of an Ancient Craft, Dover Publications: New York, 1978, $611 \mathrm{p}$.

14. Maclead, M., Early History of Coated Papers-How They Came of Age. Paper Trade Journal, 1972, pp. 170-175.

15. Zhbankov, R.G.; Firsov, S.P.; Buslov, D.K.; Nikonenko, N.A.; Marchewka, M.K.; Ratajczak, H. Structural physicochemistry of cellulose macromolecules. Vibrational spectrum and structure of cellulose. Journal of Molecular Structure, 2002, 614, pp. 117-125.

16. Derrick, M.R.; Stulik, D.; Landry, J.M.; Infrared Spectroscopy in Conservation Science. The Getty Conservation Institute, Los Angeles, 1999, $251 \mathrm{p}$.

17. Baker, M; Van der Reyden, D.; Ravenel, N. FTIR Analysis of Coated Papers, The Book and Paper Group, 1989 , Vol. 8, (http://cool.conservation-us.org/coolaic/sg/bpg/annual/v08/bp08-01.html)

18. Vetter, W.; Schreiner, M.; Characterization of Pigment-Binding Media Systems - Comparison of Non-Invasive in-Situ Reflection FTIR with Transmission FTIR Microscopy. e-PRESERVATION Science, 2011, 8, pp. 10-22. 